\title{
Analisis Brand Equity Perguruan Tinggi Swasta di Bandar Lampung
}

\author{
Aswin Aswin, Cahyani Pratisti*, Muhammad Saputra \\ Institut Informatika dan Bisnis Darmajaya, Lampung \\ *email: cahyanipratisti@darmajaya.ac.id,
}

\begin{tabular}{|c|c|}
\hline$A R T I C L E \quad I N F O$ & $A B S T R A C T$ \\
\hline $\begin{array}{l}\text { Artikel History: } \\
\text { Received:June 9, } 2021 \\
\text { Revised: July 29, } 2021 \\
\text { Published: July 31, } 2021\end{array}$ & $\begin{array}{l}\text { Business competition among education services in Bandar Lampung is rapidly } \\
\text { raising, including private universities. Brand equity is proven to increase the } \\
\text { universities profitability in the long term. This qualitative research aims to provide } \\
\text { a comparison of the brand equity among private universities in Bandar Lampung. } \\
\text { Through descriptive analysis and cochran q-test from } 560 \text { combined informants } \\
\text { from high school and collegues found that in high school IIB Darmaiava was Top of }\end{array}$ \\
\hline $\begin{array}{l}\text { Keywords: } \\
\text { Brand equity, University }\end{array}$ & $\begin{array}{l}\text { mind IIB Darmajaya, Recall brand was Technocrats University, and Brand } \\
\text { recognition that they knew IIB Darmajaya from friends and family. Whereas the } \\
\text { collegues obtained Top of mind was IIB Darmajaya, Brand recall IIB Darmajaya } \\
\text { was identical to Computer Science and Economics, Brand recognition } \\
\text { recognizes IIB Darmajaya from logos, slogans and taglines, Brand association that } \\
\text { IIB Darmajaya had a good image, good quality private campus, an innovative } \\
\text { campus, had a variety of student activities, and Brand loyalty in good categories } \\
\text { also. Promotional activities both directly and digitally to high school students } \\
\text { absolutely needed to improve IIB Darmajaya's brand recall. }\end{array}$ \\
\hline
\end{tabular}

\section{N F O A R T I K E L}

Riwayat Artikel:
Diterima: 9 Juni 2021
Direvisi: 29 Juli 2021
Dipublikasikan: 31 Juli 2021

Kata kunci:

Brand equity, Perguruan Tinggi

\section{A B S T R A K}

Persaingan bisnis antar jasa pendidikan di Bandar Lampung semakin pesat, tak terkecuali perguruan tinggi swasta. Ekuitas merek dalam jangka panjang terbukti dapat meningkatkan profitabilitas perguruan tinggi. Penelitian kualitatif ini bertujuan untuk memberikan perbandingan ekuitas merek perguruan tinggi swasta di Bandar Lampung. Melalui analisis deskriptif dan uji cochran q-test dari informan siswa/i SMA/sederajat sebanyak 250 orang dan mahasiswa/i 410 mahasiswa, didapat bahwa pada siswa/i SMA/sederajat Top of mind Perguruan Tinggi Swasta adalah IIB Darmajaya, Brand recall Universitas Teknokrat, dan Brand recognition mengetahui merek Darmajaya dari teman dan keluarga. Sedangkan pada mahasiswa/i didapat Top of Mind Perguruan Tinggi Swasta adalah IIB Darmajaya, Brand recall IIB Darmajaya identik dengan ilmu komputer dan ilmu ekonomi, Brand recognition mengenali IIB Darmajaya dari logo, serta slogan dan tagline, dan Brand association IIB Darmajaya memiliki citra yang baik, kampus swasta yang bermutu, kampus yang inovatif, memiliki ragam kegiatan mahasiswa, serta Brand loyalty dalam kategori baik. Kegiatan promosi baik secara langsung maupun digital kepada siswa/i SMA diperlukan untuk meningkatkan brand recall IIB Darmajaya. 


\section{PENDAHULUAN}

Orientasi jasa pendidikan tinggi kini telah mengalami perubahan yang signifikan. Orientasi tersebut berubah dari yang dahulu merupakan lembaga nirlaba, kini menjadi lembaga yang berorientasi profit. Perubahan tersebut muncul akibat semakin tingginya kebutuhan akan jasa pendidikan tinggi yang berkualitas. PoPddikti.go.id (2020) mencatat sedikitnya terdapat 4.504 unit perguruan tinggi yang menyebar diseluruh Indonesia yang terdiri dari Perguruan Tinggi Negri (PTN) sebanyak 122 unit dan Perguruan Tinggi Swasta (PTS) sebanyak 3.136 unit. Artinya, jumlah PTS kini 26 kali lebih banyak dibandingkan PTN. Perbandingan tersebut tentu membuat persaingan antar PTS menjadi lebih ketat. Anggapan masyarakat terhadap PTS pun kini berubah dari yang dahulu menjadi perguruan tinggi pilihan kedua setelah tidak diterima di Perguruan Tinggi Negri (PTN), kini dapat menjadi pilihan utama seiring semakin banyaknya kualitas PTS yang mampu bersaing dengan PTN. Hal tersebut tentunya semakin tingginya persaingan PTS.

Brand merupakan salah satu intangible aset perusahaan yang yang paling bernilai. Brand merupakan pembeda suatu produk dengan produk lainnya dan merupakan alat pengambilan keputusan bagi konsumen karena brand merepresentasikan persepsi dan perasaan konsumen tentang produk dan performanya. Brand yang benar-benar bernilai dapat terlihat dari kemampuannya menjadi pilihan konsumen dan seberapa besar konsumen loyal terhadap brand tersebut (Pinar et.al, 2014). Perusahaan jasa terus berupaya untuk menguatkan brand mereka, tak terkecuali PTS. Branding menjadi langkah strategis untuk mengkomunikasikan perbedaan sebuah PTS dengan PTS lainnya (Jevons, 2006 in Pinar et.al, 2014).

Seiring semakin banyaknya jumlah PTS di Bandar Lampung, maka menjadi sebuah tantangan bagi PTS yang ada di Bandar Lampung untuk tetap memenangkan pangsa pasar, dalam hal ini calon mahasiswa. Salah satu indikator bahwa PTS tersebut berkualitas di mata konsumen adalah dengan menjadi preferensi atau pilihan konsumen dan konsumen loyal kepada PTS tersebut. Tingkat preferensi yang tinggi dan loyalitas konsumen merupakan bagian dari Brand Equity yang baik. Brand equity penting bagi perusahaan dan juga bagi konsumen, bagi konsumen brand equity merupakan atribut-atribut yang diinginkan sebagai dasar untuk membangun emosional yang kuat dengan sebuah brand dan merupakan elemen keunggulan kompetitif (Mourad, Ennew \& Kortan, 2011). Aaker (1991) menyatakan bahwa brand equity membantu konsumen menginterpretasikan, memroses, menyimpan, dan mendapatkan kembali sejumlah informasi tentang produk dan brand, mempengaruhi kepercayaan konsumen dalam melakukan keputusan pembelian, dan mempengaruhi kepuasan konsumen ketika menggunakan sebuah produk seperti merepresentasikan beberapa atribut 
seperti performa produk yang lebih baik, mereduksi risiko, menekan biaya pencarian informasi sehingga memperkuat brand equity (Mourad, Ennew \& Kortan, 2011). Sedangkan dari sisi perusahaan, brand equity dapat berasal dari berbagai perspektif termasuk financial market, perusahaan, karyawan, dan saluran komuikasi (Mourad, Ennew \& Kortan, 2011). Aaker (1997) menyatakan ada 5 sumber yang menjadi asset bagi brand equity, yaitu: brand loyalty, brand awareness, perceived brand quality, brand associations, dan asset brand lainnya seperti paten, merek dagang, dan lainnya.

Menurut Aaker (1997) dalam Humdiana (2005), brand awareness adalah kesanggupan seorang calon pembeli untuk mengenali atau mengingat kembali bahwa suatu merek merupakan bagian dari kategori produk tertentu. Damayanti (2019) mengkategorikan menjadi empat tingkatan brand awareness, yaitu: 1). Unware of brand, 2). Brand recognition, 3). Brand recall, dan 4). Top of mind.

Aaker (1997) dalam Humdiana (2005) mendefiniskan brand association (asosiasi merek) sebagai segala hal yang berkaitan dengan ingatan mengenai sebuah merek. Sebuah merek adalah seperangkat asosiasi, biasanya terangkai dalam bentuk yang bermakna. Pada umumnya asosiasi merek menjadi pijakan konsumen dalam keputusan pembelian dan loyalitasnya pada merek tersebut. Dalam prakteknya, didapati banyak sekali kemungkinan asosiasi dan variasi dari brand association (Bernard, 2018), diantaranya: 1). Help process/ retrieve information, 2). Differentiate, 3). Reason to buy, 4). Create positive attitude/ feelings, 5). Basic for extentions.

Perceived quality adalah persepsi pelanggan terhadap kualitas atau keunggulan suatu produk atau layanan ditinjau dari fungsinya secara relatif dengan produk- produk lain (Simamora,2001). Perceived Quality dibagi menjadi tujuh dimensi, yaitu:1). Kinerja, 2). Pelayanan, 3). Ketahanan, 4). Keandalan, 5). Karakteristik produk, 6). Kesesuaian dengan spesifikasi, 7). Hasil.

Menurut Aaker (1997), brand loyalty merupakan satu ukuran keterkaitan seseorang pelanggan pada sebuah merek. Bila brand loyalty terhadap suatu merek meningkat, kerentanan kelompok pelanggan tersebut dari ancaman dan serangan merek produk pesaing dapat dikurangi. Dengan demikian brand loyalty merupakan salah satu indikator inti dari brand equity yang jelas terkait dengan peluang penjualan, yang berarti pula jaminan perolehan laba. Ariyadi (2015) mengkategorikan tingkatan brand loyalty dengan suatu produk, yaitu: 1). Switcher, 2). Habitual buyer, 3). Satisfied buyer, 4). Like the brand, 5). Commited buyer.

Gary, et al. (2005) juga menyatakan brand equity memiliki efek positif dari mengenali nama merek Perguruan Tinggi swasta (PTS) bahkan hingga menjadi sangat loyal terhadap PTS tersebut. 
Banyak perusahaan penyedia jasa rela membayar lebih demi mendapatkan brand equity yang baik karena brand equity terbukti mampu meningkatkan profit perusahaan dalam jangka panjang.

Karena semakin beragamnya tuntutan konsumen atas jasa pendidikan tinggi dan banyaknya pemain di Bisnis jasa pendidikan tinggi, maka menjadi sebuah tantangan bagi PTS untuk memiliki brand equity yang tinggi, sehingga kemungkinan konsumen dalam hal ini calon mahasiswa untuk berkuliah di PTS tersebut besar. Brand equity yang tinggi juga dapat menjadi indikasi bagi estimasi banyaknya calon mahasiswa yang akan mendaftar di lembaga pendidikan tinggi tersebut.

Tabel 1. Daftar Universitas, Institut, Sekolah Tinggi, dan Akademi di Bandar Lampung

\begin{tabular}{|c|c|c|}
\hline No & Nama & Jenis \\
\hline 1 & Universitas Bandar Lampung & Universitas \\
\hline 2. & Malahayati & Universitas \\
\hline 3. & Universitas Teknokrat Indonesia & Universitas \\
\hline 4. & Universitas Muhammadiyah Lampung & Universitas \\
\hline 5. & Universitas Saburai & Universitas \\
\hline 6. & Universitas Tulang Bawang & Universitas \\
\hline 7. & Institut Informatika dan Bisnis Darmajaya & Institut \\
\hline 8. & Sekolah Tinggi Ilmu Ekonomi Gentiaras & Sekolah Tinggi \\
\hline 9. & Sekolah Tinggi Ilmu Kesehatan Mitra Lampung & Sekolah Tinggi \\
\hline 10. & Sekolah Tinggi Ilmu Pertanian Surya Dharma & Sekolah Tinggi \\
\hline 11. & Sekolah Tinggi Perkebunan Lampung & Sekolah Tinggi \\
\hline 12. & Sekolah Tinggi Teknik Nusantara & Sekolah Tinggi \\
\hline 13. & STIE Lampung & Sekolah Tinggi \\
\hline 14. & STIE Gentiaras & SEkolah Tinggi \\
\hline 15. & STIE Satu Nusa & Sekolah Tinggi \\
\hline 16. & STIKIP PGRI Bandar Lampung & Sekolah Tinggi \\
\hline 17. & STMIK Tunas Bangsa & Sekolah Tinggi \\
\hline 18. & STMIK Dian Cipta Cendekia & Sekolah Tinggi \\
\hline 19. & Akademi Akuntansi dan Manajemen Mitra Lampung & Akademi \\
\hline 20. & Akademi Akuntansi Lampung & Akademi \\
\hline 21. & Akademi Bahasa Asing DCC & Akademi \\
\hline 22. & Akademi Teknik Radiodiagnostik dan Radioterapi (ATRO) Patriot Bangsa & Akademi \\
\hline 23. & Akademi Kebidanan Panca Bhakti & Akademi \\
\hline 24. & Akademi Kebidanan ADILA & Akademi \\
\hline 25. & Akademi Pariwisata Satu Nusa & Akademi \\
\hline 26. & Akademi Perpajakan Tridarma & Akademi \\
\hline 27. & Amik Lampung & Akademi \\
\hline 28. & AMIK Master Lampung & Akademi \\
\hline
\end{tabular}

Sumber: Kemdikbud.co.id (2020).

Salah satu kota yang memiliki banyak Perguruan Tinggi Swasta (PTS) adalah Bandar Lampung. Kemdikbud.go.id (2020) mencatat setidaknya terdapat 28 PTS di Bandar Lampung meliputi Universitas, Institut, Sekolah Tinggi, dan Akademi. Kondisi tersebut mengindikasikan tingginya tingkat persaingan dalam merebut calon mahasiswa baru. Rincian Universitas, Institut, Sekolah tinggi, dan Akademi di Bandar Lampung dapat dilihat pada Tabel 1. 
Melihat tingginya persaingan jasa Perguruan Tinggi Swasta (PTS) di Bandar Lampung, maka penting dilakukan penelitian mengenai brand equity PTS di Bandar Lampung. Hasil penelitian dapat digunakan sebagai bahan masukan bagi penyusunan strategi pemasaran PTS sehingga memiliki brand equity yang baik dan mendapatkan jumlah mahasiswa baru yang selalu meningkat tiap tahunnya.

\section{METODE PENELITIAN}

\section{Desain Penelitian}

Penelitian kualitatif deskriptif ini dilakukan di Provinsi Lampung selama satu tahun dari bulan Mei 2019 sampai dengan Mei 2020.

\section{Populasi dan Sampel}

Populasi dalam penelitian ini berjumlah 700 orang yang terdiri dari 500 orang mahasiswa aktif IIB Darmajaya dan 200 orang siswa kelas 3 SMA/sederajad yang dipilih secara non probability sampling dengan tenik quota sampling. Adapun persyaratan siswa yang menjadi responden adalah: tertarik melanjutkan pendidikan ke jenjang yang lebih tinggi, dan dapat menggunakan google form.

\section{Teknik Pengumpulan Data}

Data yang digunakan dalam penelitian ini menggunakan data primer yang berasal dari kuesioner semi terbuka yang diuji valididtas dan reliabilitasnya menggunakan product moment dan Cronbach alpha.

\section{Teknik Analisis Data}

Data penelitian selanjutnya dianalisis dengan analisis deskriptif untuk mencari gambaran distribusi frekuensi penilaian elemen-elemen ekuitas merek, yaitu:

\section{Analisis Kesadaran Merek (Brand Awareness)}

Pengukuran dan pembahasan kesadaran merek mencakup tingkatan dari kesadaran merek (Brand Awareness) yaitu, Top of Mind (puncak pikiran), Brand Recall (pengingatan kembali merek), Brand Recognition (pengenalan merek), dan Unaware of Brand (tidak menyadari merek). Untuk mengetahui informasi mengenai Brand Awareness, responden diberikan sejumlah pertanyaan terbuka mengenai merek Perguruan Tinggi yang paling diingat (Top of Mind) dan pertanyaan mengenai Perguruan Tinggi yang diketahui setelah yang paling diingat (Brand Recall). Untuk mengetahui Brand Recognition, responden diberi pertanyaan apakah mengetahui 
merek Perguruan Tinggi IIB Darmajaya. Jika jawaban responden tidak mengetahui merek tersebut, maka masuk ke dalam kategori Unaware Brand.

2. Analisis Asosiasi Merek (Brand Association)

Pengujian terhadap berbagai asosiasi merek dilakukan dengan uji Cochran. Uji Cochran digunakan pada data dengan skala pegukuran nominal atau informasi dalam bentuk terpisah dua (dikotomi), misalnya informasi "ya" atau "tidak". Pada pengujian ini jawaban "ya" diberi skor 1 dan jawaban "tidak" diberi skor 0 .

3. Analisis Persepsi Kualitas (Perceived Quality)

Skala pengukuran yang digunakan adalah skala Likert, dengan skala masing-masing pertanyaan dibagi skor 1 (sangat tidak setuju) hingga 5 (sangat setuju).

4. Analisis Loyalitas Merek (Brand Loyalty)

Pengukuran loyalitas merek dilakukan dengan cara mengelompokkan jumlah masingmasing tingkatan dari loyalitas merek yaitu switcher, habitual buyer, satisfied buyer, liking the brand dan commited buyer dengan cara menghitung jumlah rata-rata, presentase pada responden. Untuk switcher dilakukan dengan cara menghitung jawaban responden yang menjawab "sering" dan "selalu" pada kuesioner. Untuk habitual buyer dihitung berdasarkan jawaban "setuju" dan "sangat setuju" pada kuesioner. Untuk satisfied buyer bila responden menjawab pertanyaan kuesioner dengan jawaban "puas" dan "sangat puas" pada kuesioner. Untuk liking the brand bila responden menjawab "suka" dan "sangat suka". Untuk commited buyer dihitung berdasarkan jawaban responden yang menjawab "sering" dan "selalu" pada kuesioner.

\section{HASIL DAN PEMBAHASAN}

\section{Karakteristik responden siswa SMA/sederajat}

Sebanyak 150 siswa kelas 3 SMA/sederajat didapati bertempat tinggal menyebar di Provinsi Lampung dari mulai Mesuji, Lampung Tengah, Lampung Utara, Lampung Selatan, Lampung Timur, Metro, Pringsewu, Pesawaran, dan terbanyak di Bandar Lampung (64\%). Pekerjaan terbesar orang tua adalah Wiraswasta (26,7\%) dan PNS (23,3\%). Sebagian besar siswa SMA ingin melanjutkan kuliah (88\%) di PTN (89\%) di Lampung (73,3\%). Sebanyak 64\% siswa kelas $3 \mathrm{SMA} /$ sederajat memilih perguruan tinggi dengan banyak pertimbangan (64\%) seperti:

Tabel 1. Aspek penting bagi pemilihan perguruan tinggi bagi siswa SMA/sederajat 


\begin{tabular}{lll}
\hline \multicolumn{1}{c}{ Aspek penting } & Jumlah (orang) & Presetase (\%) \\
\hline Akreditasi yang dimiliki & 118 & $78,7 \%$ \\
Kelengkapan fasilitas kampus & 75 & $50,0 \%$ \\
Tenaga pengajar (dosen) yang handal & 61 & $40,7 \%$ \\
Pilihan jurusan yang tersedia & 61 & $40,7 \%$ \\
Harga (ekonomis) & 48 & $32,0 \%$ \\
Terkenal diantara teman dan keluarga/Reputasi & 15 & $10.0 \%$ \\
\hline
\end{tabular}

Sumber: data diolah (2020)

\section{Karakteristik responden mahasiswa IIB Darmajaya}

Dari data sebanyak 500 orang mahasiswa aktif dari berbagai angkatan dan jurusan, didapat alasan mahasiswa memilih IIB Darmajaya sebagai tempat berkuliah adalah:

Tabel 2. Alasan mahasiswa berkuliah di IIB Darmajaya

\begin{tabular}{lll}
\hline \multicolumn{1}{c}{ Alasan berkuliah di IIB Darmajaya } & \multicolumn{1}{c}{ Jumlah (orang) } & Persentase (\%) \\
\hline $\begin{array}{l}\text { Mengetahui kualitas yang dimiliki } \\
\text { (Fasilitas, Program, Lulusan, Beasiswa, }\end{array}$ & 185 & $45,1 \%$ \\
dsb) & & \\
Rekomendasi dari rekan, keluarga atau teman & 167 & $40,7 \%$ \\
Promosi yang diberikan cukup menarik (Sosial & 29 & $7,1 \%$ \\
Media, brosur Dsb) & & \\
Hanya suka saja & 19 & $4,6 \%$ \\
Harga & 0 & $0 \%$ \\
Lainnya & 10 & $2,43 \%$ \\
\hline
\end{tabular}

Sumber: data diolah (2020)

\section{Kesadaran Merek (Brand Awareness) responden siswa SMA/sederajat}

\section{Top Of Mind}

Perguruan tinggi yang paling banyak diingat oleh siswa SMA/sederajat adalah IIB Darmajaya (46\%),Universitas Bandaar Lampung (UBL), Universitas Teknokrat Indonesia (UTI), Universitas Saburai, Universitas Mitra Lampung (Umitra), dan Universitas Malahayati.

\section{Brand Recall}

Satu perguruan tinggi yang diketahui setelah paling diingat didapat UTI(17,6\%),Universitas Malahayati, IIB Darmajaya, Universitas Muhammadiyah Lampung (UML), UBL, Universitas Saburai, dan Umitra.

\section{Brand Recognition dan Unaware Brand}

Terdapat 88,5\% responden yang mengingat merek IIB Darmajaya dan 3,8 \% yang perlu diingatkan kembali mengenai merek IIB Darmajaya. Unaware of brand (tidak mengenal merek IIB Darmajaya sama sekali) hanya sebesar 7,6\%. 


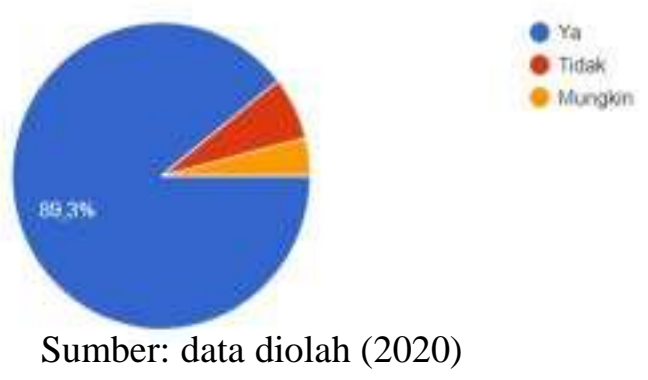

Gambar 1. Brand Recognition

Berdasarkan hasil brand recognition sebagian besar (89,3\%) mengetahui mengenai merek IIB Darmajaya dari sumber-sumber berikut:
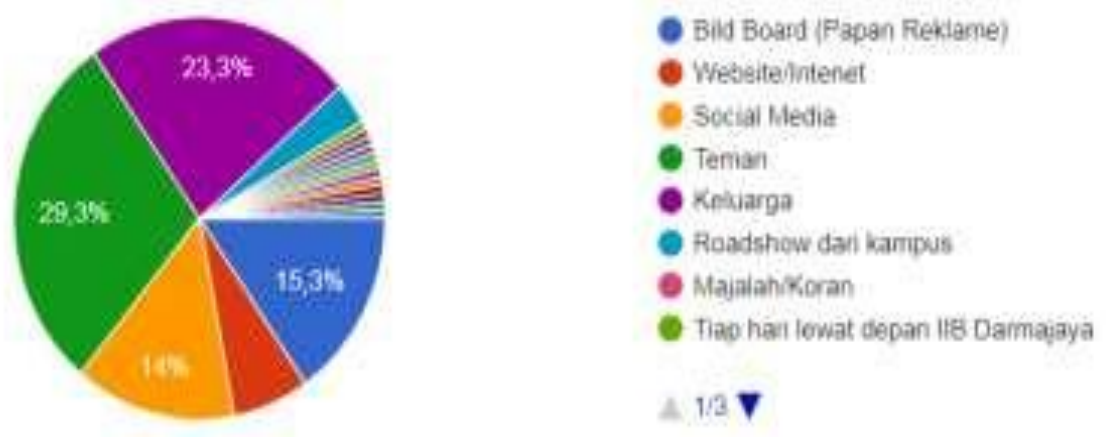

Sumber: data diolah (2020)

Gambar 2. Sumber Informasi IIB Darmajaya

Mahasiswa mengentahui mengenai IIB Darmajaya dari teman (29,3\%), keluarga sebesar (23,3\%), dan Bild Board (papan reklame) $(15,3 \%)$.

\section{Kesadaran Merek (Brand Awareness) Responden Mahasiswa Darmajaya Top of Mind}

Hasil top of mind menunjukkan IIB Darmajaya menjadi kampus yang prtama kali diingat oleh mahasiswa IIB Darmajaya, tetapi belum menjadi pilihan utama ketika mendaftar kuliah.

Tabel 3. Top Of Mind Mahasiswa IIB Darmajaya

\begin{tabular}{ccc}
\hline Pertanyaan & Ya & Tidak \\
\hline IIB Darmajaya adalah kampus yang pertama kali diingat & $56,9 \%$ & $43,1 \%$ \\
IIB Darmajaya merupakan pilihan utama saat mendaftar & $40,7 \%$ & $59,3 \%$ \\
\hline
\end{tabular}

Sumber : Data Diolah, 2020 


\section{Brand Recall}

Hasil brand recall menyatakan bahwa Ilmu Komputer dan Ekonomi identik dengan IIB Darmajaya $(90,8 \%)$ dan mengetahui setiap kegiatan promosi yang dilakukan oleh IIB Darmajaya $(62 \%)$.

\section{Brand Recognition dan Unaware of Brand}

Berikut adalah hasil Brand Recognition dan Unware of Brand IIB Darmajaya.

Tabel 4. Hasil Brand Recognition dan Unaware of Brand

\begin{tabular}{lcc}
\hline \multicolumn{1}{c}{ Pertanyaan } & Ya & Tidak \\
\hline Dapat mengenali IIB darmajaya hanya dengan melihat logonya & $89,6 \%$ & $10,4 \%$ \\
Mengingat setiap iklan IIB Darmajaya & $60,0 \%$ & $40,0 \%$ \\
Mengenali slogan/tage line yang dimiliki IIB Darmajaya & $86,9 \%$ & $13,1 \%$ \\
\hline
\end{tabular}

Sumber : Data Diolah, 2020

\section{Asosiasi Merek (Brand Association)}

Analisis atribut-atribut yang saling berhubungan dalam membentuk asosiasi merek pada IIB Darmajaya awalnya memiliki 10 atribut yaitu:

\begin{tabular}{|l|r|r|}
\hline \multicolumn{1}{|c|}{ Tabel 5. Uji 10 Asosiasi Merek IIB Darmajaya } \\
\hline \multicolumn{1}{|c|}{ Atribut } & \multicolumn{2}{|c|}{ Value } \\
IIB Darmajaya mempunyai citra/image yang baik & 0 & 1 \\
IIB Darmajaya kampus swasta yang bermutu & 5 & 405 \\
IIB Darmajaya kampus swasta yang inovatif & 3 & 407 \\
IIB Darmajaya kampus swasta terbaik di Provinsi Lampung & 7 & 403 \\
IIB Darmajaya kampus yang agamis & 15 & 395 \\
Biaya kuliah di IIB Darmajaya sesuai dengan kualitas & 23 & 387 \\
Model Pembelajaran di IIB Darmajaya mengikuti trend/up date & 87 & 323 \\
Tekonologi Informasi yang digunakan up to date & 15 & 395 \\
Fasilitas yang ada di IIB Darmajaya lengkap dan modern & 27 & 383 \\
IIB Darmajaya kampus yang memilki ragam kegiatan kemahasiswaan & 104 & 306 \\
\hline
\end{tabular}

Sumber: data diolah (2020)

Dari 10 atribut tersebut, diambil 4 atribut sebagai berikut:

Tabel 6. Uji 4 Asosiasi Merek IIB Darmajaya

\begin{tabular}{|c|c|c|}
\hline \multirow[t]{2}{*}{ Atribut } & \multicolumn{2}{|c|}{ Value } \\
\hline & 0 & 1 \\
\hline IIB Darmajaya mempunyai citra/image yang baik & 5 & 405 \\
\hline IIB Darmajaya kampus swasta yang bermutu & 3 & 407 \\
\hline IIB Darmajaya kampus swasta yang inovatif & 7 & 403 \\
\hline IIB Darmajaya kampus yang memilki ragam kegiatan kemahasiswaan & 7 & 403 \\
\hline
\end{tabular}

Sumber: data dolah (2020) 


\section{Persepsi Kualitas (Perceived Quality)}

Hasil perhitungan mengenai atribut-atribut persepsi kualitas dapat dilihat pada tabel 7 berikut:

Tabel 7. Rata-rata Atribut Persepsi Kualitas

\begin{tabular}{|c|c|c|c|c|c|c|c|}
\hline \multirow{2}{*}{ Atribut } & \multicolumn{5}{|c|}{ Jawaban Responden } & \multirow{2}{*}{ Jumlah } & \multirow{2}{*}{ Rata-rata } \\
\hline & 5 & 4 & 3 & 2 & 1 & & \\
\hline Dosen IIB Darmajaya berkualitas & 505 & 1072 & 126 & 0 & 2 & 1705 & 4,13 \\
\hline Proses pembelajaran yang unggul & 440 & 1064 & 174 & 2 & 0 & 1680 & 4,07 \\
\hline $\begin{array}{l}\text { Materi pembelajar yang diberikan } \\
\text { dosen up date }\end{array}$ & 460 & 1060 & 162 & 4 & 0 & 1686 & 4,08 \\
\hline Susana dan lingkungan belajar yang & & & & & & & \\
\hline kondusif & 465 & 1004 & 204 & 0 & 1 & 1674 & 4,05 \\
\hline $\begin{array}{l}\text { Layanan diberikan dengan baik sesuai } \\
\text { dengan kebutuhan mahasiswa }\end{array}$ & 475 & 940 & 216 & 20 & 1 & 1652 & 4,00 \\
\hline $\begin{array}{l}\text { Adil kepada semua mahasiswa dalam } \\
\text { memberikan pelayanan }\end{array}$ & 430 & 872 & 273 & 36 & 0 & 1611 & 3,90 \\
\hline $\begin{array}{l}\text { Staf pelayanan memiliki kemampuan } \\
\text { dan pengetahuan yang tinggi dalam } \\
\text { menjalankan tugas }\end{array}$ & 455 & 956 & 222 & 14 & 2 & 1649 & 3,99 \\
\hline $\begin{array}{l}\text { Staf pelayanan bersikap sopan, santun } \\
\text { dan ramah dalam melayani mahasiswa }\end{array}$ & 360 & 1104 & 189 & 4 & 0 & 1657 & 4,01 \\
\hline $\begin{array}{l}\text { Tanggapan terhadap keluhan dilakukan } \\
\text { dengan cepat }\end{array}$ & 295 & 748 & 405 & 56 & 4 & 1508 & 3,65 \\
\hline Informasi layanan sangat jelas & 395 & 1032 & 204 & 14 & 1 & 1646 & 3,99 \\
\hline $\begin{array}{l}\text { Prosedur layanan administrasi } \\
\text { terstruktur dan mudah dipahami }\end{array}$ & 380 & 1044 & 201 & 14 & 2 & 1641 & 3,97 \\
\hline $\begin{array}{l}\text { Proses pelayanan cepat dan tepat } \\
\text { waktu }\end{array}$ & 330 & 956 & 279 & 26 & 2 & 1593 & 3,86 \\
\hline $\begin{array}{l}\text { Lulusan IIB Darmajaya berkualitas } \\
\text { dan diakui }\end{array}$ & 515 & 988 & 183 & 4 & 0 & 1690 & 4,09 \\
\hline Rata-rata $S$ & luruh & Atribu & & & & & 3,98 \\
\hline
\end{tabular}

Sumber : Data diolah (2020)

Tabel 7 diperoleh nilai rata-rata keseluruhan atribut persepsi kualitas merek adalah sebesar 3,98 dan berada pada kategori baik. Nilai rata-rata tertinggi pada atribut ke 1 sebesar 4,13 mengenai Dosen IIB Darmajaya berkualitas. Sedangkan nilai rata-rata terendah ada pada atribut ke 9 sebesar 3,65 yaitu Tanggapan terhadap keluhan dilakukan dengan cepat. 


\section{Loyalitas Merek (Brand Loyalty)}

Hasil perhitungan mengenai atribut-atribut loyalitas merek dapat dilihat pada tabel 8 berikut :

Tabel 8. Rata-rata Atribut Loyalitas Merek

\begin{tabular}{|c|c|c|c|c|c|c|c|}
\hline \multirow{2}{*}{ Atribut } & \multicolumn{5}{|c|}{ Jawaban Responden } & \multirow{2}{*}{ Jumlah } & \multirow{2}{*}{ Rata-rata } \\
\hline & 5 & 4 & 3 & 2 & $\mathbf{1}$ & & \\
\hline $\begin{array}{l}\text { Menceritakan hal positif IIB Darmajaya } \\
\text { kepada orang lain } \\
\text { Membagikan info mengenai IIB } \\
\text { Darmajaya di media social }\end{array}$ & 585 & 332 & 52 & 585 & 332 & 969 & 2.35 \\
\hline \multicolumn{8}{|l|}{$\begin{array}{l}\text { Akan tetap meneruskan kuliah di IIB } \\
\text { Darmajaya meskipun perguruan tinggi lain } \\
\text { menawarkan program yang lebih baik }\end{array}$} \\
\hline $\begin{array}{l}\text { Akan tetap memilih IIB Damajaya, } \\
\text { meskipun kualitas pelayanannya belum } \\
\text { maksimal }\end{array}$ & 1122 & 276 & 45 & 1122 & 276 & 1194 & 2.89 \\
\hline $\begin{array}{l}\text { Akan tetap meneruskan kuliah meski } \\
\text { biaya kuliah mengalami kenaikan }\end{array}$ & 1008 & 138 & 8 & 1008 & 138 & 1154 & 2.79 \\
\hline $\begin{array}{l}\text { Akan tetap setia meneruskan kuliah } \\
\text { meskipun mendengar adanya informasi } \\
\text { negatif tetang IBI Darmajaya }\end{array}$ & 1116 & 70 & 6 & 1116 & 70 & 1192 & 2.89 \\
\hline \multicolumn{7}{|c|}{ Rata-rata Seluruh Atribut } & 2,71 \\
\hline
\end{tabular}

Sumber: data diolah (2020)

Tabel 8 diatas diperoleh nilai rata-rata keseluruhan atribut loyalitas merek adalah sebesar 2,71 dan berada pada kategori baik. Niai tertinggi dari 7 atibut loyalitas merek adalah pada atribut ke 3,4 dan 7 sebesar 2,89, sedangkan nilai rata-rata terendah ada pada atribut ke 2 sebesar 2,35 dan berada pada kategori cukup.

\section{Switcher}

Tabel 9. Tingkat Loyalitas Merek Switcher

\begin{tabular}{|c|c|c|c|c|c|c|}
\hline Switcher & $\mathbf{X}$ & $X^{2}$ & $\mathbf{F}$ & FX & $\mathbf{F X}^{2}$ & $\%$ \\
\hline Tidak Pernah & 1 & 1 & 131 & 131 & 17.161 & 8.26 \\
\hline Jarang & 2 & 4 & 125 & 250 & 62.500 & 30.07 \\
\hline Kadang-Kadang & 3 & 9 & 104 & 312 & 97.344 & 46.84 \\
\hline Sering & 4 & 16 & 43 & 172 & 29.584 & 14.24 \\
\hline Selalu & 5 & 25 & 7 & 35 & 1.225 & 0.59 \\
\hline Total & & & 410 & 900 & 207.814 & 100 \\
\hline Rata-rata & \multicolumn{6}{|c|}{2,2} \\
\hline Switcher (\%) & \multicolumn{6}{|c|}{$12,20 \%$} \\
\hline
\end{tabular}


Hasil perhitungan pada tabel 9 diketahui bahwa rata-rata mahasiswa IIB Darmajaya sering berpindah merek karena faktor harga dan yang benar- benar sensitif terhadap harga berjumlah 50 orang (12,20\%). Nilai rata-rata responden kategori switcher adalah 2,2 dan termasuk dalam kategori tidak baik $(1,81-2,60)$ atau tingkat switchernya rendah.

\section{Habitual Buyer}

Habitual buyer adalah membeli suatu produk berdasarkan kebiasaan, bukan berdasarkan kesetiaan terhadap merek. Konsumen memilih produk secara berulang bukan karena merek produk. Pernyataan pada habitual buyer adalah "Apakah Anda setuju bahwa alasan Anda mengkonsumsi suatu merek produk lainnya karena kebiasaan", yang termasuk ke dalam tingkatan habitual buyer adalah responden yang menjawab "setuju" dan "sangat setuju". Hasil penelitian dapat dilihat pada tabel 10 berikut :

Tabel 10. Tingkat Loyalitas Merek Habitual Buyer

\begin{tabular}{|c|c|c|c|c|c|c|}
\hline Habitual Buyer & $\mathbf{X}$ & $\mathbf{X}^{2}$ & $\mathbf{F}$ & FX & $\mathbf{F X}^{2}$ & $\%$ \\
\hline Sangat Tidak Setuju & 1 & 1 & 43 & 43 & 1,849 & 0.31 \\
\hline Tidak Setuju & 2 & 4 & 92 & 184 & 33,856 & 5.72 \\
\hline Ragu-ragu & 3 & 9 & 76 & 228 & 51,984 & 8.78 \\
\hline Setuju & 4 & 16 & 175 & 700 & 490,000 & 82.76 \\
\hline Sangat Setuju & 5 & 25 & 24 & 120 & 14,400 & 2.43 \\
\hline Total & & & 410 & 1275 & 592,089 & 100 \\
\hline Rata-rata & & & \multicolumn{2}{|c|}{3,11} & & \\
\hline Habitual Buyer (\%) & & & \multicolumn{2}{|c|}{$48,54 \%$} & & \\
\hline
\end{tabular}

Sumber: data diolah (2020)

Hasil perhitungan pada tabel 10 diketahui bahwa rata-rata responden IIB Darmajaya merasa setuju bahwa keputusan pembelian suatu produk karena kebiasaan adalah berjumlah 199 orang (48,54\%). Nilai rata-rata responden kategori habitual buyer adalah 3,11 di mana masuk ke dalam kategori cukup $(2,61-3,40)$.

\section{Satisfied Buyer}

Pada tingkatan ini pembeli merek masuk dalam kategori puas bila mereka mengkonsumsi merek tersebut. Pernyataan pada satisfied buyer adalah "Apakah anda puas selama kuliah di IIB Darmajaya", yang termasuk ke dalam tingkatan satisfied buyer adalah responden yang menjawab "puas" dan "sangat puas". Hasil penelitian dapat dilihat pada tabel 11 berikut : 
Tabel 11. Tingkat Loyalitas Merek Satisfed Buyer

\begin{tabular}{lllllrr}
\hline \multicolumn{1}{c}{ Satisfed Buyer } & $\mathbf{X}$ & $\mathbf{X}^{\mathbf{2}}$ & $\mathbf{F}$ & $\mathbf{F X}$ & $\mathbf{F X}^{\mathbf{2}}$ & \multicolumn{1}{c}{$\boldsymbol{\%}$} \\
\hline Sangat Tidak Puas & 1 & 1 & 1 & 1 & 1 & 0.00 \\
Tidak Puas & 2 & 4 & 5 & 10 & 100 & 0.01 \\
Biasa Saja & 3 & 9 & 119 & 357 & 127,449 & 12.55 \\
Puas & 4 & 16 & 222 & 888 & 788,544 & 77.66 \\
Sangat Puas & 5 & 25 & 63 & 315 & 99,225 & 9.77 \\
\hline Total & \multicolumn{7}{c}{$\mathbf{4 1 0}$} & $\mathbf{1 5 7 1}$ & $\mathbf{1 , 0 1 5 , 3 1 9}$ & $\mathbf{1 0 0 . 0 0}$ \\
\hline Rata-rata & $\mathbf{3 , 8 3}$ \\
\hline Satisfed Buyer (\%) & $\mathbf{6 9 , 5 1 ~ \%}$ \\
\hline
\end{tabular}

Sumber: data diolah (2020)

Hasil perhitungan pada tabel 11 diketahui bahwa rata-rata responden IIB Darmajaya merasa puas dan sangat puas selama kuliah di IIB Darmajaya berjumlah 285 orang $(69,51 \%)$. Nilai ratarata responden kategori satisfedl buyer adalah 3,83 di mana masuk ke dalam kategori Baik (3,41 $4,20)$.

\section{Liking The Brand}

Pembeli yang masuk dalam kategori loyalitas ini merupakan pembeli yang sungguhsungguh menyukai merek tersebut. Pernyataan pada liking the brand adalah "Apakah anda benar-benar menyukai kuliah di IIB Darmajaya", yang termasuk ke dalam tingkatan linking the brand adalah responden yang menjawab "suka" dan "sangat suka". Hasil penelitian dapat dilihat pada tabel 12 berikut :

Tabel 12. Tingkat Loyalitas Merek Linking The Brand

\begin{tabular}{|c|c|c|c|c|c|c|}
\hline Linking the brand & $\mathbf{X}$ & $\mathbf{X}^{2}$ & $\mathbf{F}$ & FX & $\mathbf{F X}^{2}$ & $\%$ \\
\hline Sangat Tidak Suka & 1 & 1 & 0 & 0 & - & 0.00 \\
\hline Tidak Suka & 2 & 4 & 2 & 4 & 16 & 0.00 \\
\hline Biasa Saja & 3 & 9 & 78 & 234 & 54,756 & 4.62 \\
\hline Suka & 4 & 16 & 242 & 968 & 937,024 & 79.05 \\
\hline Sangat Suka & 5 & 25 & 88 & 440 & 193,600 & 16.33 \\
\hline Total & & & 410 & 1646 & $1,185,396$ & 100.00 \\
\hline Rata-rata & & & \multicolumn{2}{|c|}{4,01} & & \\
\hline Linking the brand $(\%)$ & & & \multicolumn{2}{|c|}{$80,49 \%$} & & \\
\hline
\end{tabular}

Sumber: data diolah (2020)

Hasil perhitungan pada tabel 12 diketahui bahwa rata-rata responden IIB Darmajaya merasa suka dan sangat suka selama kuliah di IIB Darmajaya berjumlah 330 orang $(80,49 \%)$. Nilai ratarata responden kategori linking the brand adalah 4,01 di mana masuk ke dalam kategori Baik (3,41 $-4,20)$.

\section{Commited Buyer}

Pembeli merupakan pelanggan yang setia. Mereka memiliki suatu kebanggaan sebagai pengguna suatu merek dan bahkan merek tersebut menjadi sangat penting. Pernyataan pada commited buyer adalah "Apakah anda menyarankan dan mempromosikan ke orang lain untuk 
kuliah di IIB darmajaya", yang termasuk ke dalam tingkatan commited Buyer adalah responden yang menjawab "sering" dan "selalu". Hasil penelitian dapat dilihat pada tabel 13 berikut :

Tabel 13. Tingkat Loyalitas Merek Commited Buyer

\begin{tabular}{|c|c|c|c|c|c|c|}
\hline Commited Buyer & $\mathbf{X}$ & $\mathrm{X}^{2}$ & $\mathbf{F}$ & FX & $\mathbf{F X}^{2}$ & $\%$ \\
\hline Tidak Pernah & 1 & 1 & 4 & 4 & 16 & 0.00 \\
\hline Jarang & 2 & 4 & 31 & 62 & 3,844 & 0.57 \\
\hline Kadang-kadang & 3 & 9 & 182 & 546 & 298,116 & 44.22 \\
\hline Sering & 4 & 16 & 103 & 412 & 169,744 & 25.18 \\
\hline Selalu & 5 & 25 & 90 & 450 & 202,500 & 30.03 \\
\hline Total & & & 410 & 1474 & 674,220 & 100.00 \\
\hline Rata-rata & & & \multicolumn{2}{|c|}{3,60} & & \\
\hline Commited Buyer (\%) & & & \multicolumn{2}{|c|}{$47,07 \%$} & & \\
\hline
\end{tabular}

Hasil perhitungan pada tabel 13 diketahui bahwa rata-rata responden IIB Darmajaya memiliki suatu kebanggaan dengan respons selalu dan sering menyarankan kuliah di IIB Damajaya berjumlah 193 orang (47,07\%). Nilai rata-rata responden kategori commited buyer adalah 3,60 di mana masuk ke dalam kategori Baik $(3,41-4,20)$.

\section{KESIMPULAN}

Kesimpulan pada penelitian ini lebih spesisifik diabahas tiap bagian, yaitu pada kesadaran merek (Brand Awareness), Institut Informatika dan Bisnis (IIB) Darmajaya berada pada puncak pikiran (top of mind), sedangkan pada tingkat brand recall adalah Universitas Teknokrat (UTI). Asosiasi Merek (Brand Association), dari 10 atribut/asosiasi yang diuji diperoleh 4 asosiasi pembentuk brand image IIB Darmajaya, yaitu: 1) IIB Darmajaya mempunyai citra/image yang baik, 2) IIB Darmajaya kampus swasta yang bermutu, 3) IIB Darmajaya kampus swasta yang inovatif, 4) IIB Darmajaya kampus yang memilki ragam kegiatan kemahasiswaan. Persepsi Kualitas (Perceived Quality), nilai rata-rata keseluruhan atribut persepsi kualitas merek berada pada kategori baik dengan indicator: Dosen IIB Darmajaya berkualitas, Lulusan IIB Darmajaya berkualitas dan diakui, serta materi pembelajar yang diberikan dosen up date. Loyalitas Merek (Brand Loyalty), nilai rata-rata keseluruhan atribut loyalitas merek adalah sebesar 2,71 berdasarkan skala berada pada kategori baik. Pada tingkatan switcher adalah 2,20 masuk ke dalam kategori tidak baik dalam artian tingkat switcher adalah rendah. Pada tingkatan habitual buyer adalah 3,11 masuk ke dalam kategori cukup. Pada tingkatan satisfied buyer adalah 3,83 di mana masuk ke dalam kategori Baik. Pada tingkatan linking the brand adalah 4,01 masuk ke dalam kategori Baik dan pada tingkatan commited buyer adalah 3,60 di mana masuk ke dalam kategori Baik. 


\section{DAFTAR PUSTAKA}

Aaker, D. (1997). Managing Brand Equity. New York: The Free Press.

Aaker, D. (2014). Aaker On Branding. 20 Prinsip Esensial Mengelola dan Mengembangkan Brand. Jakarta: PT Gramedia Pustaka Utama.

Ariyadi, D. (2015). Analisis Ekuitas Merek Berbasis Pelanggan pada Minimarket Indomaret di Salatiga. Jurnal Among Makarti vol (8), no 16.

Bernard, W.T. (2018). Lifestyle Marketing, Jakarta: PT Gramedia Pusat Utama.

Cooper, Schnidler. (2011). Business Research Methods. 11th Edition. New York: McGraw-Hill Companies Inc.

Damayanti, C., Wahyono. (2019). Pengaruh Kualitas Produk, Brand Image terhadap Loyalitas dengan Kepuasan Sebagai Variabel Intervening. Management Analysis Journal vol (4) no 3.

Garry, Kotler, P., Amstrong. (2005). Dasar-Dasar Pemasaran, Jilid 1, Alih Bahasa Alexander Sindoro.

Humdiana. (2005). Analisis Elemen-Elemen Ekuitas Merek Produk Rokok Merek Djarum Black. Jakarta.

Kemdikbud.co.id (2020). Data Referensi Kementerian Pendidikan dan Kebudayaan https://referensi.data.kemdikbud.go.id/index51.php?kode=126008\&level=3 diakses tanggal 12 April 2020.

Kotler. (2005). Manajemen Pemasaran. Jakarta: Erlangga.

Kotler, P., Keller, K.L. (2009). Marketing Management. 12th Edition. New Jersey: Pearson Education, Inc., Upper Saddle River.

Mourad, M., C. Ennew., W. Kortam. (2011). Brand equity in Higher Education. Marketing Intelligent and Planning Journal, Vol. 29 Iss 4 pp. 403 - 420.

Pinar, M., P. Trapp, T. Girald, T. Boyt. (2014). University brand equity: An empirical investigation of its dimensions. International Journal of Educational Management, Vol. 28 Iss 6 pp. 616634.

Shimp, AT., Andrews, JC. (2012). Advertising, Promotion, and Other Aspecs of Integrated marketing Communications. South Western: Cengange Learning.

Simamora, B. (2001). Memenangkan Pasar dengan Pemasaran Efektif dan Profitabel, Edisi 1. Jakarta: PT. Gramedia Pustaka Utama.

Suarna, IF. (2016). Analisis Ekuitas Merek Sari Roti di Bandung. Jurnal Ekubis.

Sugiono. (2017). Metode Penelitian Kuantitatif, Kualitatif, dan R\&D. Bandung: Penerbit Alfabeta. 